\title{
USTANAWIANIE KONSTYTUCJI (TRYBY UCHWALANIA, OKTROJOWANIE I FORMY)
}

\section{Wstęp}

Ustanawianie współczesnych ustaw zasadniczych i szerzej kreacja innych aktów ustrojowych, zasługuje na wnikliwą analizę prawniczą. Niekiedy współczesne „konstytucje” nie są aktami prawnymi posiadającymi normy o najwyższej mocy, stąd posługuję się określeniem - „akty ustrojowe". Zatem celem niniejszego opracowania jest zbadanie stosowania procedur i w konsekwencji ujawnienie formy, w jakich współczesne konstytucje egzystują. Ustanawianie konstytucji polega na zastosowaniu określonej procedury (trybu), który prowadzi do uchwalenia bądź oktrojowania (nadania) ustawy zasadniczej lub innego aktu ustrojowego. W praktyce procedury te składają się ze skomplikowanych sekwencji. Współcześnie proces ten kojarzony jest najczęściej z wykorzystaniem "klasycznych" procedur demokratycznych - parlamentu lub podmiotu specjalnie powołanego do uchwalenia konstytucji - konstytuanty. Aktualnie wykorzystuje się nadal archaiczny tryb ustanawiania aktów ustrojowych, jakim jest oktrojowanie. Ta procedura stosowana jest przez państwa autorytarne, nieposiadające tradycji demokratycznych. Powszechnie stosuje się referendum, upatrując w nim szczyt osiągnięć współczesnej demokracji. Jednak niezupełnie odpowiada to prawdzie. Fakt ten zmusza do bardziej wnikliwej analizy i oceny stosowania tej instytucji.

* Prof., dr hab., Zakład Prawa Konstytucyjnego, Instytut Nauk Prawnych, Uniwersytet Rzeszowski; e-mail: sagan.st@gmail.com, https:/ / orcid.org/0000-0003-3735-311X. 
W opracowaniu przyjmuję tezę, że kreacja współczesnych aktów ustrojowych zależy od poziomu kultury prawnej i politycznej danego społeczeństwa. Analizie poddawane są ustawy zasadnicze i inne akty ustrojowe, z przełomu XX i XXI stulecia, tzw. konstytucje piątej fali (generacji) ${ }^{1}$. Pozwala to ujawnić współczesne trendy kreacji konstytucji, chociaż sięgam także do wcześniejszych ustaw zasadniczych, historycznych.

W niniejszym opracowaniu stosuję metodę prawno-dogmatyczną. Pozwala ona odkryć specyfikę i sens (interpretację) obowiązującego tekstu prawnego, ale także wolę podmiotu stanowiącego normę oraz jego egzegezę. Pomocniczo wykorzystuję metody: komparatystyczną (prawno-porównawczą) i statystyczną. Pozwalają one na głębszy ogląd i ocenę instytucji referendum konstytucyjnego. Metoda prawno-porównawcza daje możliwość konfrontacji danej instytucji ustrojowej z jej odpowiednikami w innych państwach. Wyjaśnia nie tylko istotę innych rozwiązań, ale także pozwala na zrozumienie odmiennych koncepcji leżących u podstaw konstrukcji norm w różnych państwach. Zwykle wiąże się to także z oceną jej funkcjonowania.

Sposób ustanawiania konstytucji zależy od posiadania prawa władzy ustrojodawczej (pouvoir constituant). Jest ono integralnie związane z określeniem podmiotu władzy zwierzchniej - suwerena ${ }^{2}$. Zrazu atrybut ten przypisywano monarsze. Później władzę suwerenną złożono w ręce narodu. Stał się on zbiorowym podmiotem, z nie do końca określonym autorytetem ustrojodawczym, co zrodziło konieczność wskazania organu, który w imieniu suwerenna jest uprawniony do przygotowania konstytucji. Ewolucja ustrojowa wykształciła różne sposoby powoływania do życia ustaw zasadniczych, które są stosowane także i współcześnie. Praktykowane jest zatem powierzenie uchwalenia konstytucji grupie reprezentantów zbiorowego suwerena - może to czynić zwykły parlament lub specjalnie do tego powołany organ - konstytuanta. Wyraźnie podkreśla

1 R.M. Małajny (red.), Polskie prawo konstytucyjne na tle porównawczym, Warszawa 2013, s. 99.

2 Samo pojęcie „suwerenności” jest zabiegiem intelektualnym, używanym w dydaktyce, w szczególności dla wyjaśniania państwa, ta właśnie cecha odróżnia tę organizację od innych struktur politycznej organizacji społeczeństwa. Pojęcie to nie ma ustalonej definicji. Badane jest przez różne dyscypliny nauk społecznych. Stanowi zagadnienie multidyscyplinarne. Jest zjawiskiem wyjątkowo zmiennym w czasie. To historia poucza nas o krańcowo różnych jego znaczeniach i wymiarach. W znaczeniu potocznym jest ono kojarzone z nieograniczonością państwa. W istocie jest immanentną cechą władzy państwowej. 
się, że służy ona do przygotowania postaw ustroju i uchwalenia ustawy zasadniczej. Obywatele, wybierając do konstytuanty swoich przedstawicieli, muszą mieć pełną świadomość, iż kompletują skład, który stworzy przyszły akt ustrojowy.

\section{Ustanawianie ustaw zasadniczych przez parlament $i$ konstytuanty}

Obecnie, nadal powszechnie stosowanym sposobem jest uchwalanie konstytucji przez zwykły parlament. Jednakże, co należy podkreślić, stosuje on szczególny tryb, w którym uchwalona zostaje ustawa zasadnicza. W tradycji polskiej organ taki nosił nazwę Sejm Ustawodawczy ${ }^{3}$.

Oba te sposoby ustanowienia konstytucji przez zwykły parlament lub konstytuantę wymagają analizy, która zmierza do pokazania ich zalet i wad. Powierzenie zwykłemu parlamentowi funkcji ustrojodawczej to obciążenie go wyjątkowym obowiązkiem. Musi on równolegle wykonywać swoją podstawową funkcję ustawodawczą. Parlament jest zwykle mocno spolaryzowany politycznie. Przekłada się to na brak możliwość uzyskania kwalifikowanej większości, niezbędnej do uchwalenia ustawy zasadniczej. Praktyka ustrojowa wskazuje na niską efektywność obrad oraz poziom merytorycznych dyskusji w sprawach ustrojowych, co przekłada się na przeciąganie $\mathrm{w}$ czasie podejmowania decyzji $\mathrm{w}$ sprawach merytorycznych. Wyjątek stanowi działalność polskiego Sejmu Ustawodawczego w latach 1919-1922, który nie tylko uchwalił konstytucję, ale w czasie 342 posiedzeń plenarnych, uchwalił 571 ustaw zwykłych. Dodać trzeba, iż w czasie jego kadencji trwała wojna z bolszewikami.

3 Samo przyjęcie nazwy "Sejm Ustawodawczy" jest wyjątkowo niefortunną zbitką pojęciową, przecież podstawową funkcją każdego parlamentu jest ustawodawstwo, a tu chodzi o jego funkcję ustrojodawczą. W tradycji ustroju polskiego były dwa Sejmy Ustawodawcze. Pierwszy z nich funkcjonował w latach 1919-1922, przygotował on i uchwalił konstytucję z 17 marca 1921 r. O pracach nad konstytucją z 1921 r. pisze kompetentnie W. Komarnicki, Ustrój państwowy Polski wspótczesnej. Geneza i system, Wilno 1937, reprint dzieła wydany został w Krakowie w 2006 r., s. 30 i nn. Drugi Sejm Ustawodawczy działał w latach 1947-1952 i uchwalił konstytucję z 22 lipca 1952 r. Prace nad przebiegiem konstytucji z 1952 r. omawia K. Działocha, Geneza Konstytucji PRL, w: Konstytucja PRL po 30 latach jej obowiazywania, Wrocław 1983, s. 3 i nn. 
Drugim organem posiadającym władzę ustrojodawczą są konstytuanty. Pozytywnym aspektem ich powołania jest to, że nieobarczone bieżącą działalnością ustawodawczą mogą skupić się na szybkim przygotowaniu i uchwaleniu konstytucji. Może się to także przekładać na większy profesjonalizm w zredagowania tekstu ustawy zasadniczej. Do ich negatywnych stron zaliczyć trzeba to, że władzę ustrojodawczą powierza się reprezentantom elit politycznych, co może narażać ten organ na krytykę ograniczania samego suwerena. Ważkim problemem jest liczba przedstawicieli zasiadających $\mathrm{w}$ konstytuancie. Większą efektywność debat i ich profesjonalizm zapewniają mniejsze gremia. Jeszcze innym zagadnieniem jest brak ograniczenia czasu trwania konstytuanty. Długie procedowanie może wpływać na uformowanie się frakcji, które mogą prowadzić do braku uzyskania kwalifikowanej większości, niezbędnej do podjęcia decyzji.

\section{Referenda konstytucyjne i ich ocena}

Specyficzną rolę $\mathrm{w}$ procesie ustanawiania konstytucji odgrywa instytucja referendum konstytucyjnego. Taki sposób, po raz pierwszy, zaproponował sam Jan Jakub Rousseau. Ustawą zasadniczą, która wprowadziła ten mechanizm ustrojowy, po raz pierwszy, była ustanowiona w 1793 r. tzw. konstytucja jakobińska ${ }^{5}$. Zastosowanie tego trybu było krokiem bardziej rewolucyjnym niż samo referendum. Zainicjowało ono francuską tradycję ustanawiania kolejnych konstytucji.

Instytucja referendum upowszechniła się w wielu państwach, przenikając do różnych kultur prawnych. Poza Francją, na początku XX stulecia (w 1919 r.) do swej konstytucji wprowadziła referendum także Republika Weimarska. Zapoczątkowało to proces, który stał się wzorem "dla pożądanego ukształtowania mechanizmów partycypacji ludowej”“6. Jed-

4 O poglądach na volanté génerale J.J. Rousseau w literaturze polskiej pisze J. Grygieńć, O dialekcie dwóch koncepcji władzy w pismach Jana Jakuba Rousseau, w: Władca, władza. Literackie doświadczenia Europejczyków od antyku po wiek XIX, red. M. Szymor-Rólczak, współudz. M. Poradecki, Łódź 2011, s. 131 i nn.

5 Nie weszła ona nigdy w życie, była fasadą zbiurokratyzowanego terroru jakobińskiego, trafnie ocenił ją J. Baszkiewicz, Francja nowożytna Szkice z historii wieków XVII-XX, Poznań 2002, s. 97 i nn.

6 P. Uziębło, Demokracja partycypacyjna, Gdańsk 2009, s. 32. 
nak w okresie międzywojnia referendum czasami było wykorzystywane do legitymizowania ówczesnych reżimów autorytarnych w Europie, m.in. w krajach bałtyckich - w Estonii, Łotwie i Litwie, a także w Hiszpanii i Portugalii.

Po II wojnie światowej instytucje demokracji bezpośredniej, w tym referenda konstytucyjne, znalazły się $\mathrm{w}$ wielu konstytucjach europejskich. Współcześnie zostały recypowane m.in. w ustawach zasadniczych Szwajcarii, Francji, Włoszech, Hiszpanii, Portugalii, Grecji, Danii, Rumunii, Słowenii, Estonii czy Mołdawii. Należy zaznaczyć, że referenda konstytucyjne rozpowszechniły się względnie niedawno, stało się to bowiem w latach 80. XX w. Instytucję tę rozpoczęto stosować jako konieczny element ustanawiania i zmian we współczesnych konstytucjach. Potwierdza to wprowadzenie referendum w krajach Ameryki Łacińskiej, gdzie w taki sposób ustanowiono w latach 1999-2008 aktualne konstytucje Wenezueli, Boliwii i Ekwadoru. Odbyło się to z naruszeniem wcześniej obowiązujących w tych krajach trybów zmian ustaw zasadniczych. Ustanawianie konstytucji w tych trzech krajach odbywało się bardzo podobnie. Szermowano przy tym hasłami walki z liberalizmem, imperializmem i chęcią zerwania ze starym establishmentem.

Należy podkreślić, iż w każdym z tych krajów na różnych etapach procesu konstytucyjnego ujawniły się prawno-polityczne, mniej lub bardziej uzasadnione, zastrzeżenia co do legalności pewnych działań, decyzji organów czy też samego przyjęcia nowych konstytucji ${ }^{7}$.

Warto zwrócić uwagę na fakt, że tradycje stosowania referendum konstytucyjnego na kontynencie iberoamerykańskim są starsze - w 1934 r. zostało zastosowane w Urugwaju, a później w 1963 r. w Brazylii.

W Afryce referenda konstytucyjne wprowadzono na przełomie lat 50. i 60. w nowopowstających państwach, które zrzucały jarzmo kolonialne. Wykorzystywano je do legalizowania reżimów autorytarnych, w których konstytucje były aktami fasadowymi. Formalnie najstarszą tradycję posiada Liberia, która wprowadziła referendum konstytucyjne w 1846 r., wraz z proklamowaniem niepodległości. Współcześnie występuje ono w konstytucjach m.in. Madagaskaru, Botswany czy Kenii.

7 D. Słupik, Ustawy zasadnicze Wenezueli, Boliwii i Ekwadoru jako element rewolucji boliwariańskiej w Ameryce Łacińskiej, Studia Policae Universitatis Silesiensis 2017, t. 19, s. 155. 
W Azji najstarszą tradycję referendum konstytucyjnego posiadają Filipiny, które zastosowały tę instytucję po raz pierwszy w $1935 \mathrm{r}$. Istnieje ona nadal, choć jest ograniczona do zatwierdzania zmian wprowadzanych do konstytucji. Współcześnie, referendum konstytucyjne przyjmowane jest przez coraz większą liczbę państw m.in. Birmę (Mjanma), Tajlandię czy Mongolię.

Instytucja ta $\mathrm{z}$ trudem toruje sobie drogę, tak jak wszystkie instytucje demokracji bezpośredniej, w krajach islamskich. Obecnie jest stosowana w Turcji, Egipcie i Syrii. Najczęściej referendum konstytucyjne wykorzystywane jest w Turkmenistanie, jednak tam islam nie został głęboko zakorzeniony. Zastosowano je dziewięciokrotnie, w krótkim okresie istnienia tego państwa. Ostatnio, przy okazji zmian w konstytucji 16 grudnia 2016 r.

W Australii i Oceanii, referendum konstytucyjne stosuje Australia, gdzie po raz pierwszy w 1906 r. odbyło się glosowanie w sprawie zmian w konstytucji. Na tym obszarze stosują ją także inne nowe państwa wyspiarskie m.in. Nauru.

Referendum konstytucyjne nie jest stosowane w Ameryce Północnej na poziomie federalnym ani w Stanach Zjednoczonych, ani w Kanadzie.

W instytucji referendum konstytucyjnego upatruje się ukoronowania demokratycznego procesu zatwierdzania ustaw zasadniczych. Jednak głębsza analiza korzystania z tej instytucji ujawnia także jej niekorzystne strony. Referendum konstytucyjne jest wykorzystywane w różnych fazach procesu ustrojodawczego, m.in. w fazie upoważniania zwykłego parlamentu do przygotowania i uchwalenia konstytucji - taką procedurę zastosowano w Grecji w 1975 r. Najczęściej znajduje zastosowanie do zatwierdzania uchwalonych przez parlament lub konstytuantę ustaw zasadniczych.

Oceniając przydatność referendum w procesie ustanowienia konstytucji, należy zauważyć, że toczące się przy tej okazji debaty stanowią swoiste forum uzyskiwania informacji o treści ustawy zasadniczej, o przyjętych w niej rozwiązaniach ustrojowych. Procedura ta silnie angażuje obywateli, przeciwdziała apatii i alienacji politycznej, prowadzi do konsolidacji społeczeństwa obywatelskiego i upodmiotawia je $\mathrm{e}^{8}$, co można zaliczyć do pozytywnych efektów stosowania instytucji referendum. Na jego inicjatorach spoczywa obowiązek wdrożenia procedury, polegający

8 A. Krasnowolski, Referendum jako instytucja demokracji bezpośredniej w państwach europejskich, opracowania Biura Analiz i Dokumentacji Kancelarii Sejmu, Warszawa 2016, s. 7. 
m.in. na przygotowaniu informacji o skomplikowanych mechanizmach współczesnych instytucji ustrojowych. Ze względu na wagę konstytucji, należy unikać, $w$ fazie debat, manipulacji politycznych, które przy pomocy obecnie stosowanych technik informatycznych, mogą przyczynić się do deprecjonowania tego tak ważnego aktu ustrojowego. Równie ważkim elementem tej procedury pozostaje zachęcanie obywateli do uczestniczenia $\mathrm{w}$ referendum, niski poziom frekwencji bowiem może podważać legitymizowanie samej ustawy zasadniczej ${ }^{9}$.

W teorii konstytucji podnoszony jest także inny aspekt stosowania instytucji referendum. Wiąże się on z podejmowaniem przez reprezentantów suwerena, zgromadzonych w zwykłym parlamencie bądź w konstytuancie takich decyzji, które mogą być kwestionowane w wyniku referendum. Przyjmując, że obie formy demokracji: przedstawicielska i bezpośrednia nie wykluczają się, lecz są wobec siebie komplementarne, w przypadku referendum konstytucyjnego może to prowadzić do kolizji. A to jest przecież ten sam suweren, który $\mathrm{w}$ innej formie wyraża swoją wolę. W praktyce, w nielicznych przypadkach dochodzi do kolizji pomiędzy wynikami referendum a decyzją parlamentu bądź konstytuanty. Problem ten musi absorbować teoretyków prawa konstytucyjnego. We współczesnych ustawach zasadniczych nie ma proceduralnych norm, które pozwalałyby rozstrzygać konflikt pomiędzy wyrażaniem woli w referendum a uchwałami podjętymi $w$ ciałach reprezentujących suwerena. W przypadku braku akceptacji w referendum konstytucyjnym dla ustawy zasadniczej nie można nawet określić, $\mathrm{w}$ jakim zakresie należy poprawić odrzucony projekt, w głosowaniu referendalnym bowiem istnieje tylko opcja zerojedynkowa. Nie da się zatem określić, jakie postanowienia ustawy zasadniczej mogą być kwestionowane. Sprawa jeszcze bardziej komplikuje się w przypadku, gdy następuje odwrócenie sekwencji proceduralnej, kiedy to wyniki referendum zatwierdza parlament. Taką procedurę wprowadzono w Serbii i zastosowano ją w 2006 r. Z całą pewnością, z teoretycznego punktu widzenia, nie trzeba mieszać obu tych procedur. Podjęcie decyzji o przyjęciu określonej formy demokracji - bezpośredniej lub pośredniej - musi być konsekwentnie i zgodnie z logiką stosowane. Każda z nich posiada bowiem ciąg proceduralny, który prowadzi do bezkolizyjnego osiągnięcia celu. Nie można stosować kolizyjnych procedur do wyrażania woli w tej

9 Rozważania o ważności referendów znaleźć można w opracowaniu E. Zielińskiego, I. Bokszczanin i J. Zielińskiego, Referendum w państwach Europy, Warszawa 2003, s. 37 i nn. 
samej sprawie przez suwerena. W konsekwencji prowadzi to do powstania kolizji woli powszechnej, wyrażanej w różnych procedurach. Konsekwentne stanowisko zajmują $\mathrm{w}$ tej kwestii demokracje nordyckie (poza Danią), które unikają mieszania obu tych procedur, powierzając ustanawianie konstytucji parlamentom.

Praktyka wskazuje, że korzystanie z instytucji referendum konstytucyjnego sprzyja populistom, co może prowadzić do rywalizacji pomiędzy naczelnymi organami państwa, w szczególności głową państwa a parlamentem. Ponadto może się ono łatwo przekształcić w swoisty plebiscyt popularności partii populistycznych albo też wyrażać jedynie poparcie lub deprecjonować samych inicjatorów. To konstytucja ma przecież organizować i stabilizować byt wspólnoty narodowej i państwa. Jej treść powinna zawierać reguły normatywne, a nie stanowić zbiór populistycznych haseł. Nie może to pozycjonować tego tak ważkiego aktu jako manifestu politycznego, symbolu populistycznej formuły quasi-demokracji.

Jedną z pierwszych konstytucji, ustanowionych po II wojnie światowej, z zastosowaniem procedury referendum konstytucyjnego była konstytucja Królestwa Danii. Odbyło się ono 28 maja 1953 r. Uczestniczyło $\mathrm{w}$ nim $58 \%$ uprawnionych do głosowania. Za przyjęciem konstytucji opowiedziało się 78,8\% uczestników referendum.

Zwolennicy nowej konstytucji stanowili - przy niskiej frekwencji - zaledwie $45,8 \%$ ogółu uprawnionych do głosowania (warto przy tym podkreślić, że dotychczasowe uregulowania wymagały aprobaty $45 \%$ ogółu uprawnionych do głosowania) ${ }^{10}$.

Ten zaakceptowany akt podjęty został minimalną większością 0,8\% uprawnionych do głosowania. Zważywszy na niski poziom uczestnictwa w referendum, konstytucja została przyjęta przez mniejszość wyborców. Analogiczny obraz prezentują wyniki referendów konstytucyjnych, współcześnie stosowanych w wielu krajach na świecie. Procedura ta jest wykorzystywana coraz powszechniej. Jako przykład można wskazać kilka krajów, w których przeprowadzono referenda po 1990 r.: Rosję, Serbię, Ekwador, Egipt, Boliwię, Turcję i Wybrzeże Kości Słoniowej.

Referendum konstytucyjne w Rosji odbyło się 12 grudnia 1993 r., przy frekwencji wynoszącej 55\%. Za jej przyjęciem opowiedziało się $54,5 \%$ głosujących, przeciwko było 45,5\%. Niską frekwencję zauważa

10 M. Grzybowski, Dania. Zarys systemu ustrojowego, Kraków 2017, s. 52. 
Eugeniusz Zieliński, który opatruje to komentarzem - „wystarczyło, żeby została uchwalona konstytucja, ale nie może to wzbudzać wielkiego zachwytu co do stanu obywatelskiej aktywności wyborców Rosji okresu transformacji"11.

Serbskie referendum konstytucyjne zostało przeprowadzone $\mathrm{w}$ dniach 28 i 29 października 2006 r. Jego specyfika polegała na tym, że zastosowano procedurę, $\mathrm{w}$ ramach której wyniki referendum zatwierdzał parlament, przygotowujący konstytucję. Wzięło w nim udział 53,04\% uprawnionych do głosowania, z czego 96\% zaakceptowało konstytucję. Opozycja kwestionowała ten wynik, sugerując, że dane zostały sfałszowane, frekwencja bowiem nie przekroczyła 50\%, koniecznych do zaakceptowania ustawy zasadniczej.

Najnowsza konstytucja Ekwadoru została przygotowana i uchwalona przez konstytuantę - Zgromadzenie Konstytucyjne. Jej zatwierdzenie nastąpiło w drodze referendum, które odbyło się 28 września 2008 r. Udział w nim wzięło $75,8 \%$ uprawnionych do głosowania, za konstytucją opowiedziało się $63,93 \%$, przy $28,10 \%$ głosów przeciwnych. $W$ tym przypadku poziom uczestnictwa był wysoki.

Do krajów, które ostatnio przeprowadziły referenda konstytucyjne, należy Egipt. Odbyło się ono w dniach 14 i 15 stycznia 2014 r. Obywatele mieli zatwierdzić wyniki prac konstytuanty. Przy frekwencji wynoszącej $38,6 \%$, za konstytucją opowiedziało się 98,13\%, przeciw było 1,87\%. Tak wyjątkowo niska frekwencja przesądziła o wejściu w życie konstytucji będącej wolą mniejszości.

Jedno z najnowszych referendum konstytucyjnych przeprowadzono 30 października 2016 r. na Wybrzeżu Kości Słoniowej. Frekwencja wyniosła tam 42,42\%, za konstytucją opowiedziało się 93,42\% głosujących. Również w tym przypadku krytycy podnosili niski poziom uczestnictwa $\mathrm{w}$ referendum.

Interesujący przypadek zastosowania referendum konstytucyjnego miał miejsce w Boliwii. Przeprowadzono je 21 lutego 2016 r. Jego przedmiotem było wniesienie do konstytucji poprawki, która umożliwiłaby prezydentowi i jego zastępcy ubieganie się o trzecią kadencję. Przy frekwencji wynoszącej 84,45\% uprawionych do głosowania, za projektem opowiedziało się $48,71 \%$, przeciwnych było $51,29 \%$. W referendum

11 E. Zieliński, Wspótczesna Rosja. Studium polityczno-ustrojowe, Warszawa 1995, s. 131 i 132. 
wniosek został zatem odrzucony. Ten przypadek jest o tyle interesujący, ponieważ wskazuje, że doszło do wyraźnej kolizji pomiędzy wolą parlamentu - Kongresu Narodowego, który przyjął poprawkę zdecydowaną większością głosów 112 głosów wobec 41 przeciwnych a wolą suwerena. Ten sam parlament był inicjatorem wszczęcia procedury referendalnej 5 listopada 2015 r. Po ogłoszeniu wyników nie podjął on decyzji o rozpisaniu nowych wyborów, funkcjonuje nadal.

Najbardziej kontrowersyjne referendum konstytucyjne, w ostatnim czasie, przeprowadzono w Turcji 16 kwietnia 2017 r. Dotyczyło ono 18. poprawek do konstytucji, wniesionych przez prezydenta Recepa Tayyipa Erdoğana. Proponowane rozwiązania w istotny sposób zmieniały ustrój państwa, który z parlamentarnego stałby się prezydenckim. Wzmocniona i scentralizowana władza miała znaleźć się w rękach prezydenta. Takie działania zmierzają do demokracji fasadowej, tym bardziej że zaniechano skonstruowania jakichkolwiek mechanizmów kontroli nad tak rozległymi kompetencjami głowy państwa. Frekwencja w referendum wyniosła 85\% uprawnionych do głosowania. Za przyjęciem zmian opowiedziało się 51,4\%. Trudno ustalić rzeczywisty obraz przeciwników zmian, 1,5 mln kart do głosowania bowiem nie miało urzędowych pieczęci, ponadto karty do głosowania nie zawierały pytań, a jedynie słowa - "tak" lub "nie”. Oficjalnie uznano wyniki referendum za prawomocne. Jednak obserwatorzy Organizacji Bezpieczeństwa i Współpracy w Europie patrzą na te wydarzenia sceptycznie. Ich zdaniem referendum przeprowadzone w Turcji nie spełniło standardów międzynarodowych.

W trybie referendalnym wprowadzono także najnowszą konstytucję Kuby, przyjętą 10 kwietnia 2019 r.

Analiza współczesnych referendów konstytucyjnych na pierwszym miejscu pozwala dostrzec niski poziom uczestnictwa. Powody tego stanu rzeczy nie są do końca wyjaśnione. Najczęściej uważa się, że obywatele nie znają treści konstytucji, a także w szerszej perspektywie nie mają wiedzy o mechanizmach sterujących współczesnymi procesami władzy. Być może jednym $z$ ogniw tego procesu pozostaje zawiły sposób formułowania treści konstytucji, dlatego społeczeństwo unika wyrażania swojej woli w referendach. Jeżeli taka teza byłaby dowiedziona, to należy także przyjąć, że zawodzi sposób komunikowania się władzy z obywatelami przy wyjaśnianiu im treści ustaw zasadniczych. Obowiązek ten spoczywa na organach państwa, jest tym bardziej istotny z uwagi na fakt, że współcześnie ustanawiane konstytucje są coraz bardziej pojemne $\mathrm{w}$ treści. 
Poddając analizie instytucję referendów konstytucyjnych, nie można pominąć mechanizmu jej stosowania w USA. Referenda konstytucyjne są stałą praktyką na poziomie poszczególnych stanów, chociaż prawo ustrojowe Stanów Zjednoczonych nie przyjęło jej jako sposobu kreowania konstytucji federalnej. Jedyny wyjątek stanowi stan Delaware. Referenda konstytucyjne stosowane są zarówno w przypadku całkowitej zmiany konstytucji, jak i ich zmian częściowych, co powoduje, że jest to praktyka częsta. Stanowi niekwestionowany sposób ustanawiania konstytucji stanowych. Analiza wyników referendów przeprowadzanych w poszczególnych stanach potwierdza rezultaty uzyskiwane poza Stanami Zjednoczonymi. Uczestnictwo w tych referendach jest niskie, co więcej notuje się tam zjawisko odstąpienia od głosowania tzw. „dropoff”.

Wytłumaczeniem tego zjawiska może być niewielkie zainteresowanie wyborców przedmiotem głosowania i pośrednio wynikający z niego niski poziom wiedzy na jego temat ${ }^{12}$.

Krytycy stosowania referendum konstytucyjnego podnoszą także wysoki koszt jego organizacji.

Ryzykownym zabiegiem są próby zmiany konstytucji w tym trybie w nieugruntowanych demokracjach. Zwykle takie inicjatywy podejmują elity polityczne, które uzyskały większość parlamentarną i chcą utrwalić ten stan rzeczy w dłuższym okresie, wierząc, iż zmiana mechanizmów ustrojowych im w tym pomoże. Pozoruje się i uzasadnia konieczność zmian, wykorzystując tzw. inicjatywy społeczne, które de facto są sterowane i manipulowane odgórnie.

\section{Oktrojowanie konstytucji}

Innym sposobem, który prowadzi do ustanowienia konstytucji jest oktrojowanie. Ten termin pochodzi z francuskiej praktyki ustrojowej. Określono ją jako nadawanie (narzucanie) konstytucji przez

12 K. Zwierzchowski, Referendum z mocy prawa w procesie uchwalania i zmian konstytucji stanowych w USA, w: Konstytucjonalizm w państwach anglosaskich, red. A. Zięba, Kraków 2013, s. 451 i 452. 
monarchę - la constitution octroyée. W ten sposób ustanowiono większość aktów ustrojowych w XIX w.

Oktrojowanie stosował Napoleon, który na zajmowanych przez siebie terytoriach tworząc nowe twory państwowe, narzucał oktrojowane akty ustrojowe. W taki sposób uzyskało konstytucję Księstwo Warszawskie w dniu 22 lipca 1807 r. ${ }^{13}$ Także car Rosji Aleksander I oktrojował ustawę konstytucyjną Królestwa Polskiego w dniu 24 grudnia 1815 r. $^{14}$ Do konstytucji oktrojowanych na ziemiach polskich w XIX w. zaliczyć także należy akty ustrojowe Wolnego Miasta Krakowa. Były one nadawane przez przedstawicieli trzech zaborców Austrii, Prus i Rosji. W okresie ok. trzydziestu lat istnienia tego mini-państwa nadano mu trzy konstytucje: 3 maja 1815 r., 15 lipca 1818 r. i 29 lipca 1833 r. Fenomen tych aktów polegał na tym, że nadawali je zaborcy, chociaż w założeniu było państwem niezależnym ${ }^{15}$.

Najbardziej znana i często powoływana w historii ustrojów jest Karta Konstytucyjna z dnia 4 czerwca 1814 r. Ludwika XVIII' ${ }^{16}$. W takim samym trybie powołano kolejną francuską konstytucję z 14 sierpnia 1830 r. (data jej opublikowania), którą nadał Ludwik Filip I ${ }^{17}$. Poprzez oktrojowanie ustanowiono dwie inne konstytucje - 25 kwietnia cesarz Ferdynand I nadał konstytucję Austrii. Miała ona obowiązywać w krajach austriackich, wyłączając Węgry ${ }^{18}$. W tym też roku, w grudniu, oktrojowano konstytucję w Prusach. ${ }^{19}$ Zarówno w Austrii, jak i Prusach pierwsze oktrojowane akty konstytucyjne, nadawane pod wpływem ruchów społecznych, w okresie Wiosny Ludów były epizodem. W praktyce nie weszły w życie. Znacznie bardziej stabilną rolę odegrały dwie następne konstytucje oktrojowane w tych państwach. Wydana w grudniu 1867 r. konstytucja przetrwała

13 A. Ajnenkiel, Polskie konstytucje, Warszawa 1982, s. 89 i nn.

14 Tamże, s. 127 i nn.

15 P. Cichoń, O rzadach prawa w Wolnym Mieście Krakowie (uwag kilka), Krakowskie Studia z Historii Państwa i Prawa 2012, t. 5, z. 3, s. 241 i nn.

16 M. Morabito, D. Bourmaud, Historia konstytucyjna i polityczna Francji $(1789$ - 1958), tłum. A. Jamróz, Białystok 1996, s. 210.

17 Tamże, s. 240 i nn.

18 H. Wereszycki, Historia Austrii, wyd. 2, Wrocław 1986, s. 203 i 204; także S. Grodziski, Porównawcza historia ustrojów państwowych, Kraków 1998, s. 271.

19 W. Czapliński, A. Galos, W. Korta, Historia Niemiec, Wrocław-Warszawa-Kraków 1990, s. 486. 
do końca istnienia dualistycznego cesarstwa ${ }^{20}$. Natomiast w Prusach 31 stycznia 1850 r. król Fryderyk Wilhelm IV dokonał rewizji konstytucji z 5 grudnia 1848 r. i ogłosił jej nowy tekst. Ta regulacja przekształciła kraj w monarchię konstytucyjną oraz wprowadziła zasadę państwa prawa (Rechtsstaat). Zrewidowana konstytucja wraz z wniesionymi do niej poprawkami obowiązywała aż do 1919 r. ${ }^{21}$.

Poza Europą tryb referendum konstytucyjnego zastosował cesarz Pedro I, nadając Brazylii 25 marca 1824 r. monarchiczny akt ustrojowy ${ }^{22}$. Warto podkreślić, że poza Brazylią państwa Ameryki Łacińskiej nie posiadały aktów stanowionych w trybie oktrojowania ${ }^{23}$. Także w Japonii cesarz nadał ustawę zasadniczą $\mathrm{w}$ dniu 11 lutego 1889 r. wzorowaną na konstytucji Prus z 1850 r. w drodze reskryptu. Określana jako Konstytucja Meiji weszła w życie 29 listopada $1890 \mathrm{r}^{24}$

Postępujące procesy demokratyczne w XX w. wpłynęły na sposoby ustanawiania konstytucji. Praktycznie odstąpiono od oktrojowania ${ }^{25}$. Ale nadal, nawet w XXI stuleciu, praktykują tę procedurę autorytarne monarchie, należące do kultury islamu, głównie w Zatoce Perskiej. Do tego kręgu zalicza się Arabię Saudyjską, której świecki akt ustrojowy został nadany przez króla Fahda ibn Abduleziza Al-Sauda 2 marca 1992 r. - Podstawowy Akt o Sprawowaniu Rządów ${ }^{26}$. Jest uważany za najważniejszy akt ustrojowy, który uzupełniony został dwoma innymi: Aktem o Radzie Konsultacyjnej i Aktem o Prowincjach (noszą tę samą datę). Innym istotnym aktem ustrojowym jest Akt o Radzie Ministrów z 21 sierpnia 1993 r. Zostały one nadane w formie dekretów władcy. Te specyficzne źródła prawa wskazuje Grzegorz Małachowski, który ustala, że

20 H. Wereszycki, Historia Austrii..., s. 231.

21 К.Г. Фэдоров, История государства и права зарубежных стран, Ленинград 1977, s. 260 .

${ }^{22}$ Konstytucja Federacyjnej Republiki Brazylii, tłum. A. Wojtyczek-Bonnand, wstęp K. Wojtyczek, Warszawa 2004, s. 7.

23 Pisze o tym K. Complak, Parlament we współczesnej Ameryce Łacińskiej, Wrocław 1994, s. 9 i nn.; prezentuje ewolucję konstytucjonalizmu w tych państwach od ich powstania w początkach XIX stulecia.

${ }^{24}$ A. Kość, Filozoficzne podstawy prawa japońskiego w perspektywie historycznej, Lublin 2001, s. 84 i 85.

25 B. Banaszak, Prawo konstytucyjne, Warszawa 1999, s. 55. Przyjął, że obecnie ten tryb nie jest wykorzystywany, jednakże nadal taki sposób jest stosowany.

26 G. Małachowski, System konstytucyjny Arabii Saudyjskiej, Warszawa 2011, s. 23. 
w Królestwie Arabii Saudyjskiej najważniejsze prawa noszą nazwę nizam i stanowione są przez władcę za pomocą dekretów królewskich (marsum al-maliki) i rozkazów królewskich (amar al.-maliki). Dekret królewski i rozkaz posiadają taką samą moc prawną, dlatego czasami oba pojęcia tłumaczone są jako dekret ${ }^{27}$.

Podobnie uczynił sułtan Omanu, Qaboos bin Said Al Said, który dekretem nadał 6 listopada 1996 r. tzw. „prawo podstawowe”28. Wcześniej, bo 11 listopada 1962 r. oktrojował konstytucję emir Kuwejtu Abdullah al-Salim al-Sabah ${ }^{29}$. W tym trybie nadano konstytucję Katarowi, zastrzegając jednakże, iż wprowadzone 8 czerwca 2004 r. przez emira Hamada bin Khalifa Al-Thani „Najwyższe Prawo Państwa Kataru zostało wcześniej zaaprobowane $\mathrm{w}$ referendum przeprowadzonym 29 kwietnia $2003 \mathrm{r} .{ }^{30} \mathrm{Nie}$ był to zatem akt w pełni oktrojowany.

Poza państwami leżącymi w Zatoce Perskiej, chociaż nadal pozostając w kręgu kultury islamu, oktrojowaną konstytucję posiada Brunei. Została nadana 29 września 1959 r. ${ }^{31}$

\section{Formy współczesnych aktów ustrojowych}

Zdecydowana większość współczesnych konstytucji ustanowiona jest w formie jednego aktu. Jednak w kilku państwach na konstytucję składa się kilka ustaw zasadniczych. Jako przykład można podać Szwecję, która posiada cztery akty ustrojowe:

- Akt o Formie Rządu (Regeringsformen) z 28 lutego 1974 r.,

- Akt o Sukcesji (Successionsordningen) z 25 września 1810 r.,

- Akt o Wolności Druku (Tryckfrihetsförordningen),

${ }^{27}$ Akty konstytucyjne Królestwa Arabii Saudyjskiej, tłum. z języka arabskiego i wstęp G. Ł. Małachowski, Warszawa 2019, s. 14.

28 Oman Constitution, www.servat.unibe.ch/icl/mu00000_html; szerzej o tej konstytucji pisze Basmah Al.-Kiyumi, The Omani Constitution: A Critical Analysis, 2011, www.escholar.manchester.ac.uk/api/datastream?publicationPid=uk-ac-man-scw:164244 \&datastreamId=FULL-TEXT.PDF.

29 Oficjalny tekst konstytucji Kuwejtu, www.servat.unibe.ch/icl/Ku00000_.html.

30 Oficjalny tekst konstytucji Kataru, www.wipo.int/edocs/lexdocs/laws/en/qa/ qa009en.pdf.

31 Tekst konstytucji Brunei, www.wipo.int/wipolex/en/text.jsp?file_id=198527. 
- Akt o Wolności Wypowiedzi (Yttrandefrihetsgrundlagen) z 14 listopada 1991 r. $^{32}$.

Taka sama liczba aktów ustrojowych została nadana przez monarchę w Arabii Saudyjskiej.

Ustrój współczesnej Republiki Czeskiej regulują dwa akty ustrojowe. Są to: Konstytucja Republiki Czeskiej (Ústava České Republiky) oraz Karta Podstawowych Praw i Wolności (Listina Základních Práv a Svobod). Oba te akty noszą datę 16 grudnia 1992 r. ${ }^{33}$

Dwa akty ustrojowe posiada Królestwo Danii. Jest to Konstytucja Danii (Danmarks Riges Grundlov) z 5 czerwca 1953 r., oraz Akt o Sukcesji Tronu (Tronfolgelov) z 27 marca $1953 \mathrm{r}^{34}$.

Cechą charakterystyczną konstytucji austriackiej jest to, że w jej skład wchodzą zarówno akty ustrojowe prawa wewnętrznego, jak i prawa międzynarodowego, traktatowego. A zatem jest to konstrukcja skomplikowana i unikalna. Składa się na nią autorska konstytucja kelsenowska z 1920 r., jej częścią jest także liczący dwa artykuły traktat - Związkowa Ustawa Zasadnicza z 26 października 1955 r. o neutralności Austrii oraz Europejska konwencja o ochronie praw człowieka i podstawowych wolności. Źródła austriackiego prawa konstytucyjnego są wyjątkowo obszerne, są swoistym unikatem w skali światowej. Piotr Czarny i Bogumił Naleźiński stoją na stanowisku, zgodnie z którym „....normy o randze konstytucyjnej znaleźć można w ponad 300 austriackich aktach prawnych"35.

32 Warto zwrócić uwagę, iż termin "yttrande" przetłumaczono w języku polskim jako „wypowiedź”. W takim znaczeniu użył go M. Grzybowski w opracowaniu Konstytucja Królestwa Szwecji, wyd. 2 zm. i uaktual., tłum. K. Dębiński i M. Grzybowski, wstęp M. Grzybowski, Warszawa 2000, s. 117; taki ekwiwalent terminologiczny znaleźć można u. J. Kubitsky, Stownik szwedzko-polski, Toruń 2001, s. 553. Jednakże w moim przekonaniu doskonalszym ekwiwalentem terminologicznym jest termin „ekspres ja”, który stosowany jest $\mathrm{w}$ tłumaczeniach angielskich.

33 Szerzej o nich pisze M. Kruk, Konstytucja Republiki Czeskiej, Warszawa 1994, s. 24 i nn.; warto sięgnąć do opracowania R. Davida, Ústava České Republiky Listina Základnych Práv a Svobod, Úplne zneni dopelněné poznámki, Úvodem do problematyki a výběrem ze soudích př́padů, Olomouc 2005, s. 12 i nn. - jest to syntetyczny komentarz do czeskiej konstytucji.

34 Konstytucja Królestwa Danii, tłum. i wstęp M. Grzybowski, Warszawa 2002, s. 41 i 63.

35 Konstytucja Austrii, tłum. i wstęp P. Czarny i B. Naleźiński, Warszawa 2004, s. 14. 


\section{Zakończenie}

Konstytucje i inne akty ustrojowe mają służyć nade wszystko społeczeństwu a nie - jak wielu uważa nadal - władzy. Mają stanowić instrument ustrojowy przydatny obywatelom, a ich respektowanie zawsze zależy od poziomu kultury politycznej danego społeczeństwa. Bowiem tylko ono ma zdolność legitymizowania władz publicznych. Konstytucje są nie tylko aktami prawnymi, ale stanowią istotny czynnik państwowości oraz tożsamości narodu i jego wartości. Dlatego też ustanawianie ustaw zasadniczych jest zabiegiem niezwykle istotnym. Współcześnie, kreacja tych aktów ustrojowych odbywa się zarówno poprzez uchwalanie ich w organach przedstawicielskich, jak i coraz powszechniej korzysta się z instytucji ogólnokrajowego referendum konstytucyjnego, które jest jednym z elementów tzw. demokracji plebiscytarnej. Tę uważa się niekiedy za najbardziej demokratyczny sposób podejmowania decyzji ogólnonarodowych. Warto zwrócić uwagę na to, że w przypadku kreowania konstytucji ma ona wiele istotnych wad. Należą do nich dyskusje społeczne prowadzone przed referendum, w których narrację narzucają stronnictwa o eklektycznej ideologii populistycznej. To one wekslują dyskusję nad wartościami zawartymi w tym akcie ustrojowym bardziej w kierunku manifestu politycznego niż aktu prawnego, który ma być podstawą całego systemu prawnego i stabilizatorem wspólnoty narodowej.

Ponadto za istotną wadę tej formy kreacji konstytucji uznać trzeba niską frekwencję w ogólnokrajowych referendach konstytucyjnych.

Nadal stosowany jest także sposób oktrojowania aktów ustrojowych, szczególnie dotyczy to kręgu kultury prawnej islamu, który kultywuje tradycje monarchicznych i zarazem autorytarnych form rządzenia.

Większość współczesnych konstytucji ustanawiana jest w formie jednego aktu prawnego. Jednakże zdarzają się przypadki kreacji konstytucji, na które składa się kilka aktów ustrojowych. Trzeba przy tym dostrzec, że nie zawsze są to akty zawierające normy o najwyższej mocy prawnej.

Coraz częściej podnoszone jest to, że konstytucje nie mogą sprowadzać się do regulacji organizacji władz publicznych, ich funkcjonowania i katalogu praw obywatelskich, ale ma to być akt organizacyjny życia społecznego, efektywny mechanizm politycznej organizacji społeczeństwa. Dlatego powinny być w nim zawarte reguły dotyczące ekologii czy też dostępu do zasobów naturalnych. Nie można tracić z oczu faktu, że pozostaje ona aktem posiadającym najwyższą moc prawną. 
Oceny dotyczące wartości zawartych w konstytucjach nie mogą być zawłaszczane przez określone stronnictwa polityczne i tym bardziej przez nie oceniane. O treści konstytucji nie może przesądzać duch ksenofobii, nieufności i lęk przed światem, jej prawdziwą wartością bowiem powinno być otwarcie się na ducha wspólnoty. Dokonując interpretacji konstytucji w czasach nam współczesnych, należy uwzględniać coraz większą ilość zmiennych, biorąc pod uwagę m.in. kontekst wartości zawartych $\mathrm{w}$ innych kulturach prawnych.

\section{Bibliografia}

Ajnenkiel A., Polskie konstytucje, Warszawa 1982.

Akty konstytucyjne Królestwa Arabii Saudyjskiej, tłum. z j. arabskiego i wstęp G.Ł. Małachowski, Warszawa 2019.

Banaszak B., Prawo konstytucyjne. Zbiór przepisów, Warszawa 1999.

Baszkiewicz J., Francja nowożytna. Szkice z historii wieków XVII-XX, Poznań 2002.

Cichoń P., O rządach prawa w Wolnym Mieście Krakowie (uwag kilka), Krakowskie Studia z Historii Państwa i Prawa 2012, t. 5, z. 3.

Complak K., Parlament we wspótczesnej Ameryce Łacińskiej, Wrocław 1994.

Czapliński W., Galos A., Korta W., Historia Niemiec, Wrocław-Warszawa-Kraków 1990.

David R., Ústava České Republiky Listina Základnych Práv a Svobod, Úplne zneni dopelnĕné poznámki, Úvodem do problematyki a výběrem ze soudích př́padů, Olomouc 2005.

Działocha K., Geneza Konstytucji PRL, w: Konstytucja PRL po trzydziestu latach obowiazywania, Wrocław 1983.

Grodziski S., Porównawcza historia ustrojów państwowych, Kraków 1998.

Grygieńć J., O dialekcie dwóch koncepcji władzy w pismach Jana Jakuba Rousseau, w: Wtadca, władza. Literackie doświadczenia Europejczyków od antyku po wiek XIX, red. M. Szymor-Rólczak, współudz. M. Poradecki, Łódź 2011.

Grzybowski M., Dania. Zarys systemu ustrojowego, Kraków 2017.

Komarnicki W., Ustrój państwowy Polski wspótczesnej. Geneza i system, Wilno 1937 (reprint dzieła Kraków 2006).

Konstytucja Austrii, tłum. i wstęp P. Czarny, B. Naleźiński, Warszawa 2004.

Konstytucja Federacyjnej Republiki Brazylii, tłum. A. Wojtyczek-Bonnand, wstęp K. Wojtyczek, Warszawa 2004.

Konstytucja Królestwa Danii, tłum. i wstęp M. Grzybowski, Warszawa 2002.

Konstytucja Królestwa Szwecji, wyd. 2 zm. i uaktual., tłum. K. Dębiński, M. Grzybowski, wstęp M. Grzybowski, Warszawa 2000. 
Konstytucja Republiki Czeskiej z 16 grudnia 1992 r., tłum. i wstęp M. Kruk Warszawa 1994.

Kość A., Filozoficzne podstawy prawa japońskiego w perspektywie historycznej, Lublin 2001.

Krasnowolski A., Referendum jako instytucja demokracji bezpośredniej w państwach europejskich, opracowania Biura Analiz i Dokumentacji Kancelarii Sejmu, Warszawa 2016.

Kubitsky J., Słownik szwedzko-polski, Torun 2001.

Małachowski G., System konstytucyjny Arabii Saudyjskiej, Warszawa 2011.

Małajny R.M. (red.), Polskie prawo konstytucyjne na tle porównawczym, Warszawa 2013.

Morabito M., Bourmaud D., Historia konstytucyjna i polityczna Francji (1789-1958), tłum. A. Jamróz, Białystok 1996.

Słupik D., Ustawy zasadnicze Wenezueli, Boliwii i Ekwadoru jako element rewolucji boliwariańskiej w Ameryce Łacińskiej, Studia Policae Universitatis Silesiensis 2017, t. 19.

Uziębło P., Demokracja partycypacyjna. Wprowadzenie, Gdańsk 2009.

Wereszycki H., Historia Austrii, wyd. 2, Wrocław 1986.

Zieliński E., Wspótczesna Rosja. Studium polityczno-ustrojowe, Warszawa 1995.

Zieliński E., Bokszczanin I., Zieliński J., Referendum w państwach Europy, Warszawa 2003.

Zwierzchowski K., Referendum z mocy prawa w procesie uchwalania i zmian konstytucji stanowych w USA, w: Konstytucjonalizm w państwach anglosaskich, red. A. Zięba, Kraków 2013.

Фэдоров К.Г., История государства и права зарубежных стран, Ленинград 1977.

\section{Materiały źródłowe ze stron internetowych}

Basmah al-Kiyumi, The Omani Constitution: A critical analysis, 2011, www.escholar. manchester.ac.uk/api/datastream?publicationPid=uk-ac-man-scw: $164244 \&$ datastreamId=FULL-TEXT.PDF.

Konstytucja Brunei, www.wipo.int/wipolex/en/text.jsp?file_id=198527.

Konstytucja Kataru, www.wipo.int/edocs/lexdocs/laws/en/qa/qa009en.pdf.

Konstytucja Kuwejtu, www.servat.unibe.ch/icl/Ku00000.html.

Konstytucja Omanu, www.servat.unibe.ch/icl/mu00000.html.

\section{Streszczenie}

Ustanawianie konstytucji zasługuje na wnikliwą analizę prawniczą. Polega na zastosowaniu określonej procedury, która prowadzi do uchwalenia bądź oktrojowania (nadania) ustawy zasadniczej lub innego aktu ustrojowego. Konstytucje 
nie są tylko aktami prawnymi, ale stanowią istotny czynnik państwowości oraz tożsamości narodu i jego wartości. Współcześnie kreacja tych najważniejszych aktów ustrojowych odbywa się zarówno poprzez ich uchwalanie w parlamentach i konstytuantach, jak i coraz powszechniej wykorzystywana jest instytucja referendum. Nadal stosowane jest oktrojowanie konstytucji. Większość współczesnych konstytucji ustanawiana jest w formie jednego aktu prawnego, jednakże zdarzają się przypadki konstytucji, na które składa się kilka aktów ustrojowych. Nie zawsze są to akty zawierające normy o najwyższej mocy prawnej.

Słowa kluczowe: konstytucja, konstytuanta, przedstawicielstwo narodowe, referendum

\section{ADOPTING A CONSTITUTION. (PROCEDURES, IMPOSING A CONSTITUTION AND OTHER TYPES OF CONSTITUTIONS)}

\section{S u m m a ry}

The process of adopting a constitution deserves an in-depth legal analysis. It consists of applying specific procedures that resulting in adoption of or granting imposition giving of a constitutions (octroyed) or other act of the political system. The constitutions are not only legal acts, but they constitute an important factor in the statehood and identity of the nation and its values. Nowadays, the passing creation of these most important legal acts takes place through their adoption in parliaments and constituent assemblies; however, the institution of the referendum is more and more often used. Also, octroyed constitutions still occur. Most of the modern constitutions are established in the form of one legal act; however, there are cases of the constitutions, that consists of several constitutional acts. They are not always acts containing norms with the highest legal force.

Key words: constitution, constituent assembly, national representation, referendum

\section{ПРИНЯТИЕ КОНСТИТУЦИИ (ПОРЯДОК ПРИНЯТИЯ, ОКТРОИРОВАНИЕ И ФОРМЫ)}

\section{Резюме}

Принятие конституции заслуживает тщательного юридического анализа. Оно включает применение определенной процедуры, которая приводит к установлению или октроированию (дарование высшей властью конституции или другого конституционного акта). Конституции являются не только 
нормативно правовыми актами, но и представляют собой важный фактор государственности и самобытности нации и ее ценностей. В настоящее время создание этих наиболее важных конституционных учредительных актов происходит одновременно через их принятие парламентами и округами, но также все чаще используется институт референдума. По-прежнему используется октроирование конституции. Большинство современных конституций принимаются в форме единого правового акта, однако есть случаи, когда конституция состоит из нескольких правовых актов, закрепляющих государственный строй. Не всегда являются актами, содержащими нормы, имеющие высшую юридическую силу.

Ключевые слова: конституция, учредительное собрание, национальное представительство, референдум 